\title{
Intrathoracic fracture-dislocation of the humeral head. Is removal of the humeral head necessary?
}

\author{
Naude Du Plessis, ${ }^{1}$ Simon Rajendran, ${ }^{1}$ Syed Ali Naqi, ${ }^{1}$ Ronan Cahill ${ }^{2}$ \\ ${ }^{1}$ Department of Surgery, Royal College of Surgeons in Ireland, Dublin, Ireland \\ ${ }^{2}$ Department of Surgery, Beaumont Hospital, Dublin, Ireland
}

Correspondence to Dr Simon Rajendran, simonrajendran@gmail.com

\section{DESCRIPTION}

We present a case of a 68-year-old female who presented to the emergency department with shortness of breath and right shoulder pain after falling down a flight of stairs. Chest $\mathrm{x}$-ray revealed multiple rib fractures and a large haemothorax on the right side (figure 1A). x-Ray of the humerus showed a complex fracture of the surgical neck of the humerus with deficient bone at the site of the humeral head (figure 1B,C). A chest drain was inserted and CT revealed displacement of the humeral head into the thoracic cavity with no evidence of vascular injury (figure 2). Chest drain was removed 5 days later and humeral fracture was managed conservatively. She was discharged home 2 weeks later and is well 6 months after injury.

Intrathoracic humeral dislocation-fracture is rare, with only nineteen cases accounted for in the literature since described by West in 1949. ${ }^{2}$ The mechanism of injury is likely to be forced adduction against the inside of the chest wall. Initial radiographs may not reveal the injury and, therefore, diagnosis can be difficult. Adjunctive imaging with CT may aid diagnosis and will also evaluate the relation of fracture fragments to major vessels. Four previous cases were managed conservatively while surgery may be indicated in patients with pre-existing lung disease. $^{2}{ }^{3}$ Our case underlines the importance of clinical correlation with imaging and highlights in the absence of intrathoracic complication, the removal of the humeral head may not be necessary.

Competing interests None.

Patient consent Obtained.

\section{REFERENCES}

1. Anderson M, Rose P, Jacofsky DJ, et al. Intrathoracic fracture-dislocation of the proximal humerus: a case report and report of a new surgical technique. $J$ Trauma 2007;63:920-3.

2. Boyer $\mathbf{P}$, Alsac JM, Ettori MA, et al. Four-part fracture after intrathoracic displacement of the humeral head: a case report and review of the literature. Arch Orthop Trauma Surg 2007;127:651-4.

3. Daffner SD, Cipolle MD, Phillips TG. Fracture of the humeral neck with intrathoracic dislocation of the humeral head. J Emerg Med 2010;38: 439-43.

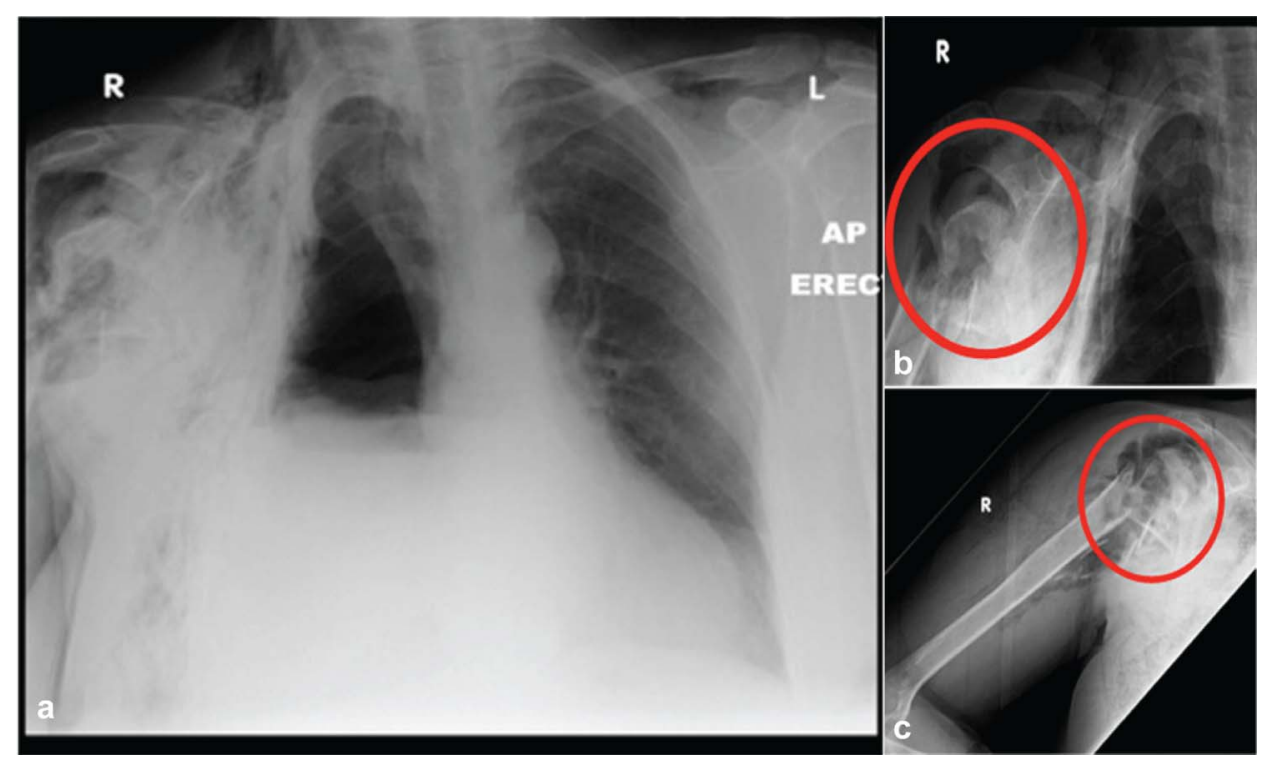

Figure 1 (A) Chest x-ray showing pneumohaemothorax and multiple rib fractures with associated subcutaneous emphysema. (B and C) $\mathrm{X}$-ray of the right shoulder showing a complex fracture of the surgical neck of the humerus with deficient bone at the site of the humeral head. 


\section{BMJ Case Reports}

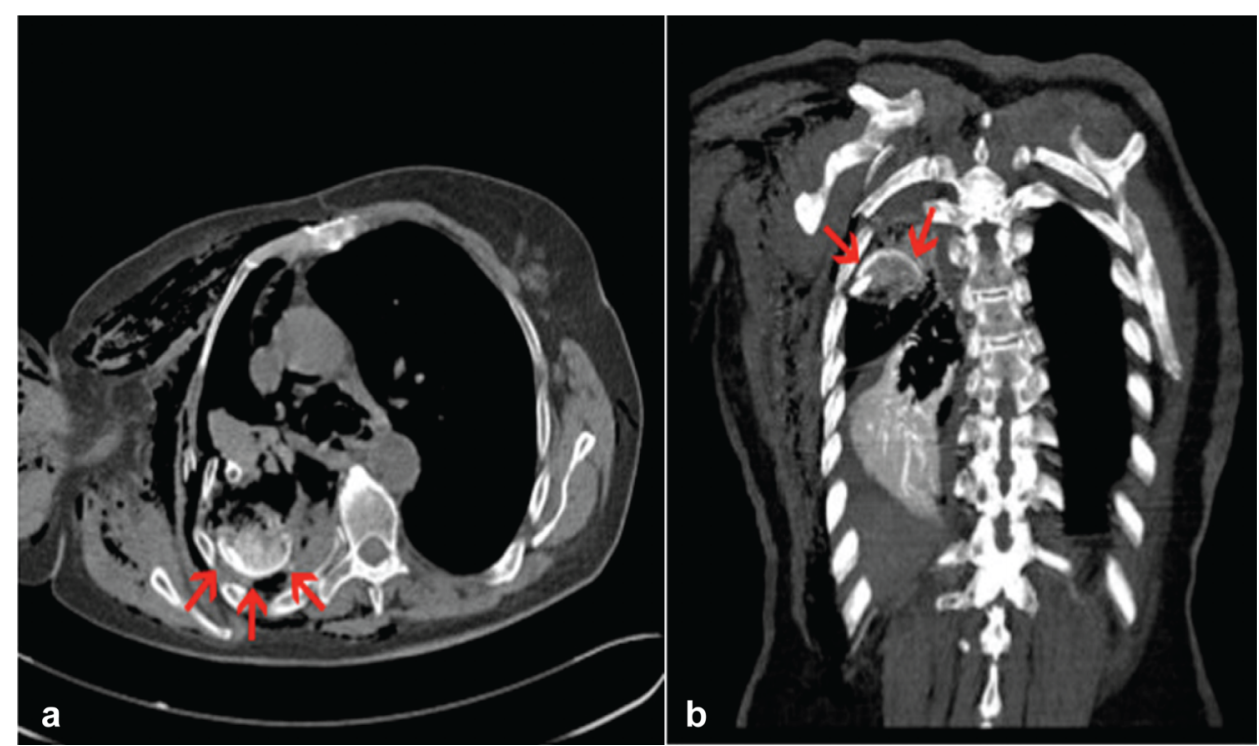

Figure 2 Axial $(A)$ and coronal $(B)$ images demonstrating intrathoracic displacement of humeral head. Note the associated haemopneumothorax and multiple rib fractures.

Copyright 2012 BMJ Publishing Group. All rights reserved. For permission to reuse any of this content visit http://group.bmj.com/group/rights-licensing/permissions.

BMJ Case Report Fellows may re-use this article for personal use and teaching without any further permission.

Please cite this article as follows (you will need to access the article online to obtain the date of publication).

Du Plessis N, Rajendran S, Nagi SA, Cahill R. Intrathoracic fracture-dislocation of the humeral head.

Is removal of the humeral head necessary?. BMJ Case Reports 2012;10.1136/bcr-2012-007478, Published XXX

Become a Fellow of BMJ Case Reports today and you can:

- Submit as many cases as you like

- Enjoy fast sympathetic peer review and rapid publication of accepted articles

- Access all the published articles

- Re-use any of the published material for personal use and teaching without further permission

For information on Institutional Fellowships contact consortiasales@bmjgroup.com

Visit casereports.bmi.com for more articles like this and to become a Fellow 